Original Research Paper

\title{
Rice Yield Related to Fertilizers Applied by Farmers on Two Areas of Marginal Peat Soil in Bengkulu Indonesia
}

\author{
${ }^{1}$ Muhammad Faiz Barchia, ${ }^{2}$ Andi Ishak, ${ }^{3}$ Satria Putra Utama and ${ }^{3}$ Ridha Rizki Novanda \\ ${ }^{I}$ Department of Soil Science, Faculty of Agriculture, University of Bengkulu, Bengkulu, Indonesia \\ ${ }^{2}$ Bengkulu Assessment Institute for Agricultural Technology, Bengkulu, Indonesia \\ ${ }^{3}$ Department of Socio-Economics, University of Bengkulu, Bengkulu, Indonesia
}

\author{
Article history \\ Received: 25-10-2020 \\ Revised: 01-01-2021 \\ Accepted: 09-01-2021 \\ Corresponding Author: \\ Muhammad Faiz Barchia \\ Department of Soil Science, \\ Faculty of Agriculture, \\ University of Bengkulu, \\ Bengkulu, Indonesia \\ Email: faizbarchia@unib.ac.id
}

\begin{abstract}
The research was intended to identify amounts of fertilizers applied by small-scale farmers related to rice yield cultivated on marginal peat soils in irrigated paddy fields in Bengkulu. The study was conducted at two peat areas; Pekik Nyaring Village, Air Hitam irrigated rice fields in Central Bengkulu and Sumber Makmur Village, Air Manjuto irrigated areas, Mukomuko Bengkulu Province from June to September 2020. A combination of purposive, snowballing samples was used to find 65 farmers as key informants. Collected data and information about fertilizers applied by farmers for paddy cultivation. Multiple regression analysis was used to find cumulative and partial contribution and significance effect of the fertilizers applied to rice yields. The result showed that fertilizers applied by the farmers significantly increase rice yield but the fertilizers played not great portion and urea fertilizer gave the highest contribution. Rice yield harvested by farmers was lower compare to the average rice productivity in Bengkulu because the doses of fertilizers applied were lower than the recommend dose. Rice yield can be improved through increasing the fertilizers dose. Optimum dose of fertilizers applied should be $567 \mathrm{~kg}$ Urea ha $^{-1}, 323 \mathrm{~kg} \mathrm{SP}-36 \mathrm{ha}^{-1}, 790$

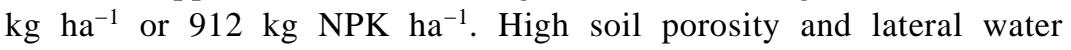
conductivity however may cause inefficiency of fertilizers applied in marginal peat soils because soluble nutrients in peat solution carried out the fertilizers from root zone by water flow.
\end{abstract}

Keywords: Fertilizers, Irrigated, Low Productivity, Marginal Peat Lands, Paddy Yield

\section{Introduction}

Rice is a strategic commodity in Indonesia (Mariyono, 2014) due to the status as the main staple food (Aprillya et al., 2019a). However, rice production in Indonesia is insufficient to meet population needs (Mustikarini and Santi, 2020). In 2019, rice production in Indonesia was about $54.6 \mathrm{M}$ tons harvested from rice fields of 10.67 Mha (BPS-Statistics Indonesia, 2020). Furthermore, since 2000, Indonesia has begun importing rice which reached its peak in 2018 with a total import of $2.14 \mathrm{M}$ tons. If Indonesia does not want to depend on rice imports, paddy production must continue to be increased (Aprillya et al., 2019b).

Indonesian government had targeted of rice selfsufficiency and to become the world's food basket by
2045 (Sulaiman et al., 2018). Considering limitations in the availability of highly productive arable land, development and optimizing of peatland for paddy production is an alternative option to ensure national food security (Surahman et al., 2018). The area of peatland in Indonesia covers about 16 to 27 Mha (Jaya et al., 2018; Page et al., 2007) or about 20.073 Mha (Rieley et al., 1996) and in Bengkulu covered about 63,000 ha (Wahyunto et al., 2004). However, the utilization of peatland for agriculture faces many obstacles such as acidity, low base saturation, organic acid toxicity and nutrient deficiency (Septiyana et al., 2017) both macro and micronutrients (Maftu'ah and Nursyamsi, 2019).

Peat soil is marginal soil for agriculture due to its low fertility (Ompusunggu et al., 2020). Peat contains an abundance of Nitrogen $(\mathrm{N})$, but a low in mineral 
nutrients. In addition, the nitrogen is mainly in form of organic nitrogen, which is not directly available to plants (Moilanen et al., 2010). Peat soils are acidic in nature ( $\mathrm{pH}$ 3.3-4.7), low content of exchangeable bases and total $\mathrm{P}_{2} \mathrm{O}_{5}$ and $\mathrm{K}_{2} \mathrm{O}(\mathrm{HCl} 25 \%)$ (Hikmatullah and Sukarman, 2014). The physical constraints of peat soil related to low nutrients availability, high macro-pore flow and soil hydraulic conductivity (Kechavarzi et al., 2010; Mustamo et al., 2016) causing nutrients leached (Maftu'ah et al., 2014). Based on these properties, the peat soils were grouped as oligotrophic (Wheeler and Proctor, 2000) ombrogenous peat (Sahfitra et al., 2020). Therefore, an appropriate management of marginal peat soil for rice cultivation is necessary to overcome these various constraints.

The fertility status of peat soils can be improved by applying an optimum fertilization (Allamah et al., 2018). Deficiency of N, P and K nutrients will cause less optimum on plant growth, while the excessive amount of $\mathrm{N}, \mathrm{P}, \mathrm{K}$ nutrients can both inhibit plant growth and cause environmental pollution (Duan et al., 2007). Rice yields were increased by applying fertilizer $\mathrm{N}, \mathrm{P}$ and $\mathrm{K}$ in sufficient amounts $(90 \mathrm{~N}, 90$ $\mathrm{P}_{2} \mathrm{O}_{5}$ and $90 \mathrm{~kg} \mathrm{~K}_{2} \mathrm{O} \mathrm{ha}^{-1}$ ) to overcome deficiencies and maintain soil fertility (Dogbe et al., 2015). N, P and $\mathrm{K}$ fertilizers affected the growth and the flowering time of rice (Ye et al., 2019). Furthermore, the grain numbers per panicle increased by 31.4, 23.9 and $48.2 \%$ and the panicle numbers increased by 55.1, 29.2 and $6.7 \%$ after application of $\mathrm{N}, \mathrm{P}, \mathrm{K}$ fertilizers. Application of $315 \mathrm{~kg}$ urea ha ${ }^{-1}, 35 \mathrm{~kg} \mathrm{SP}-36 \mathrm{ha}^{-1}$ and $90 \mathrm{~kg} \mathrm{KCl} \mathrm{ha}{ }^{-1}$ resulted in the best effects on the growth of rice plants grown on the peat tidal lowland indicated by the highest both maximum number of tillers and productive tillers (Aksani et al., 2018).

Recommendation rate of $\mathrm{N}$ fertilizer for rice was with low productivity ( 5 tons ha ${ }^{-1}$ ) needed $200 \mathrm{~kg}$ urea ha ${ }^{-1}$, medium productivity (5-6 tons $\mathrm{ha}^{-1}$ ) needed $250-300 \mathrm{~kg}$ urea $\mathrm{ha}^{-1}$ and high productivity ( $>6$ tons $\mathrm{ha}^{-1}$ ) needed 300-400 kg urea ha- (Buresh, 2010). $\mathrm{P}$ and $\mathrm{K}$ recommendation following government legislation for rice cultivation adjusted to nutrient status in soil in low nutrient status of $\mathrm{P}$ and $\mathrm{K}$ was $100 \mathrm{~kg} \mathrm{SP36}$ and $100 \mathrm{~kg}$ $\mathrm{KCl} \mathrm{ha}{ }^{-1}$, medium status of $\mathrm{P}$ and $\mathrm{K}$ was $75 \mathrm{~kg} \mathrm{SP36}$ $\mathrm{ha}^{-1}$ and $50 \mathrm{~kg} \mathrm{KCl} \mathrm{ha}^{-1}$ and in high nutrient status of

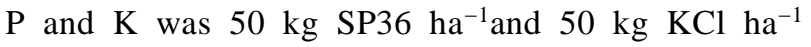
(Samijan et al., 2017). High productivity (5.73 \pm 0.49 $\mathrm{t} \mathrm{ha}^{-1}$ ) was produced from the application of $60 \mathrm{~kg}$ $\mathrm{P}_{2} \mathrm{O}_{5} \mathrm{ha}^{-1}$ or about166 kg SP36 ha $\mathrm{ha}^{-1}$ in tidal peat soil (Masganti and Nurmili, 2017). Therefore, each region has different soil fertility characteristics, so that the recommended fertilizer rate is less relevant to the varying soil fertility conditions in each region.
Most peatlands in Bengkulu had been built irrigation dam and channel facilities such as irrigation infrastructures of Air Manjuto covered areas 9,493 ha, Air Alas 4,500 ha, Air Seluma 7,467 ha, Air Riak Siabun 1,500 ha, Air Hitam 1,500 ha, Peninjauan 1,411 ha and Penago 1,084 ha (Zulkarnain, 2016). Some parts of rice fields in these irrigation areas had been converted to oil palm plantation by local farmers because of lack of water supply, pest and disease attacks and low productivity of rice field and sometimes the failure of harvest due to low soil fertility (Yanti et al., 2013; Astuti et al., 2011). Therefore, evaluating fertilizers applied to marginal peat soils for rice cultivation is important for sustainable staple food production in Bengkulu. This study was aimed to determine significant effect of $\mathrm{N}$, P, K, NPK compound fertilizers and dolomite applied by small-scale farmers and optimum level of them to rice yield cultivated on marginal peat soils at two irrigated rice field in Bengkulu Indonesia.

\section{Materials and Methods}

A case study was to evaluate $\mathrm{N}, \mathrm{P}, \mathrm{K}, \mathrm{NPK}$ compound fertilizers and dolomite applied by smallscale farmers related to rice yields cultivated on marginal peat soils at 2 (two) irrigated peat rice fields in Bengkulu; Sumber Makmur village, Air Manjuto irrigated area in Mukomuko Regency and Pekik Nyaring Village, Air Hitam irrigated area in Central Bengkulu Regency, Bengkulu Province (Fig. 1) conducted from June to September 2020. Flow chart of the research showed in Fig. 2.

Good climatic conditions and landscapes covering the irrigated rice fields favor for intensively rice farming systems however peat soil fertility could be constraint for sustainable rice cultivation. Rainfall average $295.8 \mathrm{~mm}$ month $^{-1}$ with number rainy days of 19 days in a month. Maximum temperatures were range between $32-34^{\circ} \mathrm{C}$ and minimum temperatures range between $22-23^{\circ} \mathrm{C}$ with relative humidity in in range between $80-88 \%$. These cultivated rice fields are covered in marginal peat soils.

A combination of purposive, snowballing samples was used to find 65 farmers as informants who had planted rice on their paddy's fields. Collected data and information about the sustainable rice cultivation on marginal peat soils involved a broad attribute of ecological, economical, socio-cultural, technological and institutional and policies dimensions based on farmers perspectives. This study however only used quantitative data of the rice yields, amount of urea, $\mathrm{SP} 36, \mathrm{KCl}, \mathrm{NPK}\left(15 \% \mathrm{~N}, 15 \% \mathrm{P}_{2} \mathrm{O}_{5}, 15 \% \mathrm{~K}_{2} \mathrm{O}, 9 \% \mathrm{~S}\right)$ fertilizers and dolomite applied by the farmers on the previous planting season. 
Muhammad Faiz Barchia et al. / American Journal of Applied Sciences 2021, Volume 18: 1.8 DOI: 10.3844/ajassp.2021.1.8

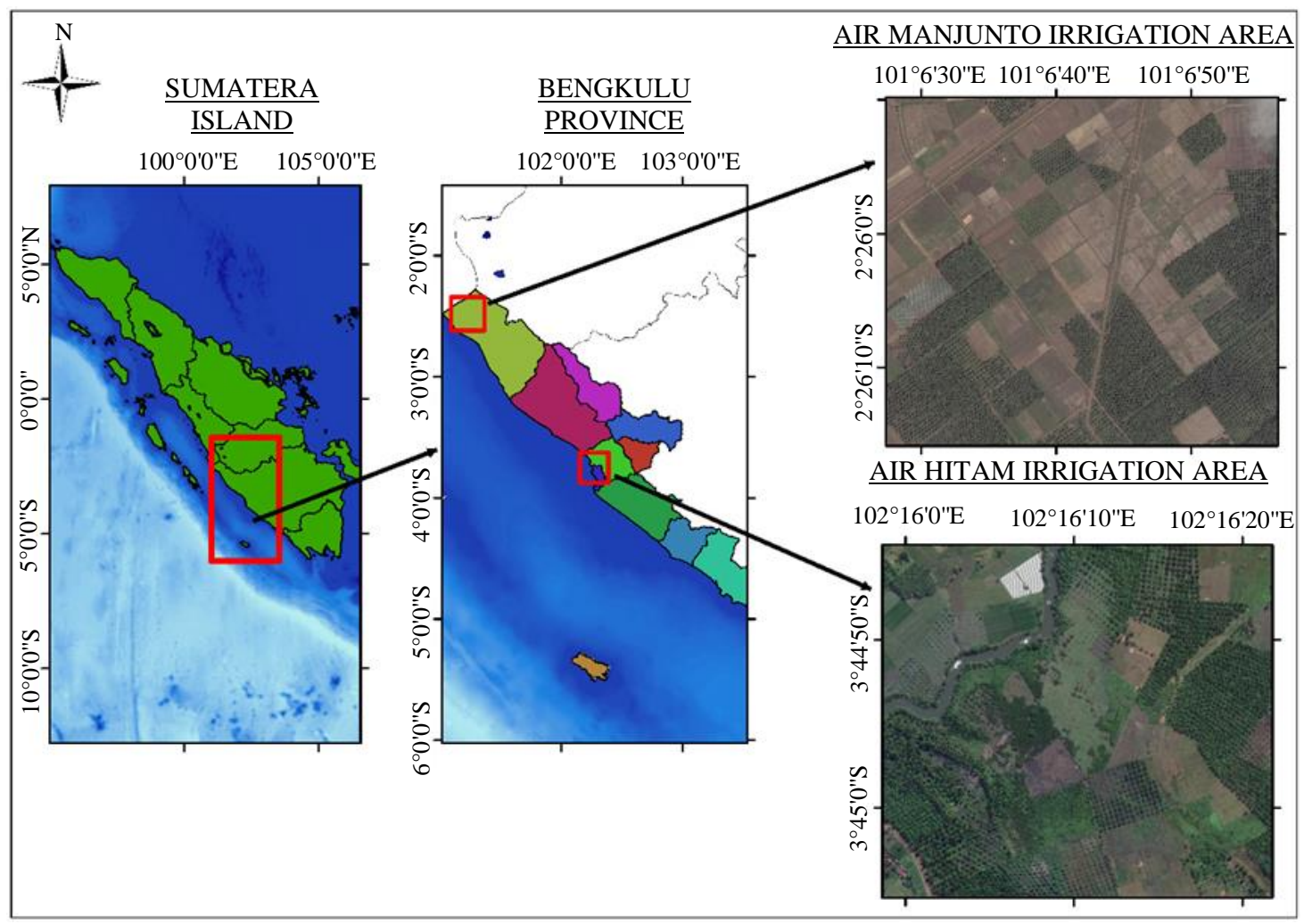

Fig. 1: Two site research of rice peat soils in Bengkulu

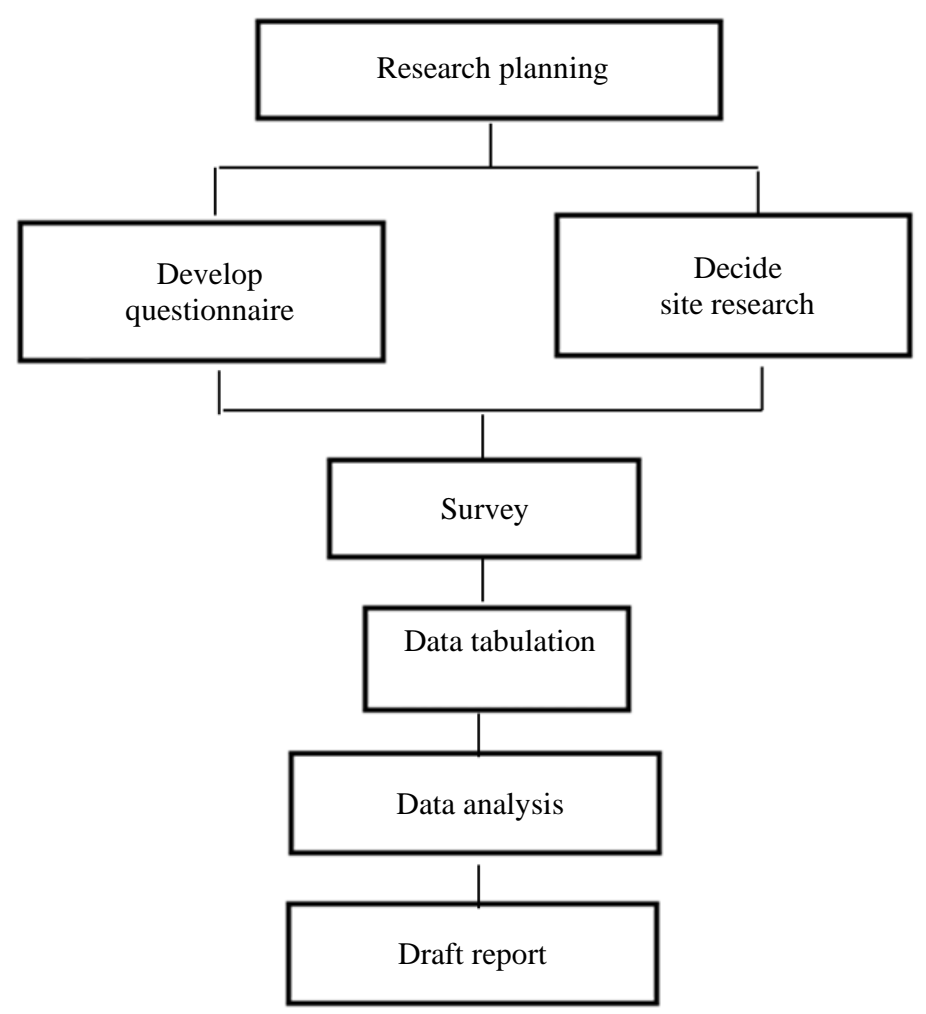

Fig. 2: Reseach flow chart 
Multiple regression analysis was used to find cumulative and partial contribution and significance effect of the fertilizers applied to rice yields. The regression model which $Y$ is the continuous response variable as dependent variable while $X_{1}, X_{2}, X p$ as the predictor variables or independent variable (Alexopoulos, 2010) revealed as follow:

$$
\begin{aligned}
& Y=\beta_{0}+\beta_{U R} X_{U R}+\beta_{S P 36} X_{S P 36}+\beta_{K C L} X_{K C L} \\
& +\beta_{N P K} X_{N P K}+\beta_{D O L} X_{D O L}+\sigma(Y)
\end{aligned}
$$

\section{Where:}

$Y \quad=$ The rice yield $\left(\mathrm{kg} \mathrm{ha}^{-1}\right)$

$\beta_{0}=$ The intercept

$\beta_{U R}=$ The regression coefficient of urea

$X_{U R}=$ Urea $\left(\mathrm{kg} \mathrm{ha}^{-1}\right)$

$\beta_{S P 36}=$ The regression coefficient of SP36

$X_{S P 36}=\operatorname{SP} 36\left(\mathrm{~kg} \mathrm{ha}^{-1}\right)$

$\beta_{K C l}=$ The regression coefficient of $\mathrm{KCl}$

$X_{K C l}=\mathrm{KCl}\left(\mathrm{kg} \mathrm{ha}^{-1}\right)$

$\beta_{N P K}=$ The regression coefficient of NPK

$X_{N P K}=\operatorname{NPK}\left(\mathrm{kg} \mathrm{ha}^{-1}\right)$

$\beta_{D O L}=$ The regression coefficient of dolomite

$X_{D O L}=$ Dolomite $\left(\mathrm{kg} \mathrm{ha}^{-1}\right)$

$\sigma(Y)=$ The residual standard deviation.

To find optimum level of each fertilizer applied, partial analysis used polynomial regression (Ekpenyong et al., 2008) between rice yield and each fertilizer applied as follow equation; for example relation between rice yield and urea applied:

$$
Y=\beta_{0}+\beta_{1} X_{U R}+\beta_{2} X_{U R^{2}}+\sigma(Y)
$$

Where:

$Y \quad=$ The rice yield $\left(\mathrm{kg} \mathrm{ha}^{-1}\right)$

$\beta_{0} \quad=$ The intercept

$\beta_{1}$ and $\beta_{2}=$ The regression coefficient of urea

$X_{U R} \quad=$ The urea $\left(\mathrm{kg} \mathrm{ha}^{-1}\right)$

$\sigma(Y) \quad=$ The residual standard deviation

The optimum dose of each fertilizer applied to rice yield could be determined from (Young and Loomis, 2014): $\beta_{1}+2 \beta_{2} X_{U R}=0$

Where:

$\beta_{1}$ and $\beta_{2}=$ The regression coefficient of urea

$X_{U R} \quad=$ The urea $\left(\mathrm{kg} \mathrm{ha}^{-1}\right)$

Multiple regression analysis and partial analysis with polynomial regression between the rice yields and each fertilizer applied used SPSS and Excel software facility.

\section{Results}

Farmers in Pekik Nyaring village, Air Hitam and Sumber Makmur village, Air Manjuto irrigation area still continue to cultivate paddy field for rice production although harvested rice indicated a low productivities. An average rice yield from previous planting calender harvested about 2,858 $\mathrm{kg} \mathrm{ha}^{-1}$ at Air Hitam area and about 3,060 kg ha ${ }^{-1}$ at Air Manjuto area and average yield from two location was about $2,982 \mathrm{~kg} \mathrm{ha}^{-1}$. The effect of fertilizers applied by farmers was significant to rice yields at the marginal peat soils on two locations with the significance value of Sig. $0.020^{*}$ as shown in Table 1.

The average rice yield 2,982 $\mathrm{kg} \mathrm{ha}^{-1}$ was based on fertilizers application with amount of $125 \mathrm{~kg}$ urea, $106 \mathrm{~kg}$ SP36, $76 \mathrm{~kg} \mathrm{KCl}, 141 \mathrm{~kg} \mathrm{NPK}$ and $167 \mathrm{~kg}$ dolomite ha ${ }^{-1}$. Coefficients and significance test of the fertilizers applied related to rice yield on marginal peat soil as shown Table 2:

$$
\begin{aligned}
& Y=2272.741+3.026 X_{U R}+1.547 X_{S P 36}-3.732 X_{K C l} \\
& +2.332 X_{N P K}+0.725 X_{D O L}+283.163 \text { with } R^{2}=0.199 *
\end{aligned}
$$

Based on the equation, application of the fertilizers by the farmers increased in rice yield to $2,982 \mathrm{~kg} \mathrm{ha}^{-1}$ comparing without fertilizer resulted in $2272.741 \mathrm{~kg} \mathrm{ha}^{-1}$, or additional increasing rice yield about $710 \mathrm{~kg} \mathrm{ha}^{-1}$ only. Application of dolomite as ameliorant for neutralizing soil $\mathrm{pH}$ and nutrient supply for calcium and magnesium almost no effect with the value $0.16 \%$ to rice yield on these marginal peat soils. Every $\mathrm{kg}$ of dolomite applied by the farmer to the rice field would increase only about $0.232 \mathrm{~kg} \mathrm{ha}^{-1}$ harvested rice grain.

Relation between rice yields and each fertilizer applied by the farmers to the paddy field on two peat soils in Bengkulu was shown in Table 3.

Table 1: Analysis of variance rice yield related to fertilizers applied

\begin{tabular}{llrlll}
\hline Model & Sum of squares & df & Mean square & F & Sig. \\
\hline Regression & $2.807 \mathrm{E} 7$ & 5 & 5614002.37 & 2.925 & $0.020^{*}$ \\
Residual & $1.133 \mathrm{E} 8$ & 59 & 1919592.23 & & \\
Total & $1.413 \mathrm{E} 8$ & 64 & & & \\
\hline
\end{tabular}


Table 2: Coefficients and significance test of the fertilizers applied

\begin{tabular}{|c|c|c|c|c|c|}
\hline \multirow[b]{2}{*}{ Variable } & \multicolumn{2}{|c|}{ Unstandardized coefficients } & \multirow[b]{2}{*}{ Std coefficient B } & \multirow[b]{2}{*}{$\mathrm{t}$} & \multirow[b]{2}{*}{ Sig. } \\
\hline & $\mathrm{B}$ & Std error & & & \\
\hline Constant & 22272.741 & 282.163 & & 8.026 & 0.000 \\
\hline Urea & 3.026 & 1.209 & 0.331 & 2.503 & 0.015 \\
\hline SP36 & 1.547 & 2.012 & 0.112 & 0.769 & 0.445 \\
\hline $\mathrm{KCl}$ & 3.732 & 2.302 & -0.345 & -1.621 & 0.110 \\
\hline NPK & 2.332 & 1.271 & 0.346 & 1.834 & 0.072 \\
\hline Dolomite & 0.725 & 1.055 & 0.125 & 0.687 & 0.495 \\
\hline
\end{tabular}

Relation between rice yield and fertilizers applied by farmers was shown in equation below

Table 3: Polynomial regression, $\mathrm{R}^{2}$, optimum level of each fertilizer applied by the farmers

\begin{tabular}{|c|c|c|c|c|c|}
\hline Fertilizer & Equation & $\mathrm{R}^{2}$ & Mean fertilizer & $\delta \mathrm{Y} / \delta \mathrm{X}=0$ & Max. rice yield \\
\hline Dolomite & $\begin{array}{l}Y=2943.3+0.2324 \\
X_{D O L}\end{array}$ & 0.0016 & 167 & & \\
\hline Urea & $\begin{array}{l}\mathrm{Y}=2272.7+8.0591 \\
X_{U R}-0.0071 X_{U R}{ }^{2}\end{array}$ & 0.1750 & 125 & 567 & 4559 \\
\hline SP36 & $\begin{array}{l}Y=2577+5.7433 \\
X_{S P 36}-0.0089 X_{S P 36} X^{2}\end{array}$ & 0.0330 & 106 & 323 & 3504 \\
\hline $\mathrm{KCl}$ & $\begin{array}{l}Y=2857.4+2.053 \\
X_{K C l}-0.0013 X_{K C l}^{2}\end{array}$ & 0.0160 & 76 & 790 & 3667 \\
\hline NPK & $\begin{array}{l}Y=2449.3+5.1077 \\
X_{N P K^{-}}-0.0028 X_{N P K^{2}}\end{array}$ & 0.1370 & 141 & 912 & 4778 \\
\hline
\end{tabular}

Application of SP36 by the farmers in an average 106 $\mathrm{kg} \mathrm{ha}^{-1}$ was not significant to rice yields. Every $\mathrm{kg}$ SP36 applied by the farmers could raise $5.7 \mathrm{~kg}$ rice grain from the cultivated peat soils. Application of $\mathrm{KCl}$ fertilizer applied by the farmers had an effect about $3.3 \%$ to the rice yield cultivated on two locations of the marginal peat soils so every $\mathrm{kg} \mathrm{KCl}$ applied would give additional harvested rice grain only about $2.052 \mathrm{~kg} \mathrm{ha}^{-1}$. NPK compound with average $141 \mathrm{~kg} \mathrm{ha}^{-1}$ contributed $13.7 \%$ to improving rice yield and each kilogram of NPK applied increased only about $5.105 \mathrm{~kg} \mathrm{ha}^{-1}$ rice grain. Urea applied by the farmers with average dose $125 \mathrm{~kg}$ $\mathrm{ha}^{-1}$ contributed only $17.5 \%$ to the harvested rice. Every $\mathrm{kg}$ urea applied to the rice field could additional increase in harvested rice grain about $8 \mathrm{~kg} \mathrm{ha}^{-1}$.

\section{Discussion}

The rice productivities from these areas were far below or about $65 \%$ only comparing to rice productivity in Bengkulu 4,603 $\mathrm{kg} \mathrm{ha}^{-1}$ and national rice productivity $5,114 \mathrm{~kg} \mathrm{ha}^{-1}$ (BPS-Statistics Bengkulu, 2020). Fertilizers applied was significantly effect to the rice yields however the application of fertilizers contributed only about 19.9\% to the harvested rice. The doses of fertilizers applied by small-scale farmers to provide available plant nutrients namely nitrogen, phosphorus, potassium, calcium and magnesium in these areas were far below the recommended doses in order to harvest in high yields.

Fertilizers applied by the farmers increased in rice yield about $710 \mathrm{~kg} \mathrm{ha}^{-1}$ and the result was slightly better than other peat areas which lime application with dolomite
$500 \mathrm{~kg} \mathrm{ha}^{-1}$ and fertilizers applied with urea $100 \mathrm{~kg} \mathrm{ha}^{-1}$, TSP $200 \mathrm{~kg} \mathrm{ha}^{-1}$ and KCl $125 \mathrm{~kg} \mathrm{ha}^{-1}$ on rice field with peat thickness $150 \mathrm{~cm}$, top soil with peat decomposition of sapric only produced rice in range 2,000-2,500 $\mathrm{kg} \mathrm{ha}^{-1}$ (Azhari et al., 2017).

Liming with dolomite was almost no effect to rice yield. From previous study, soil acidity in these field was range between $\mathrm{pH} 4.8$ and $\mathrm{pH} 5.2$ (Riwandi et al., 2009), $\mathrm{pH} 4.7$ and $\mathrm{pH} 6.1$ and cation exchange capacity (CEC) in range 29.68-81.90 $\mathrm{cmols} \mathrm{kg}^{-1}$ (Akmaldi et al., 2020). Ameliorated acid peat soil with doses of dolomite up to $10,000 \mathrm{~kg} \mathrm{ha}^{-1}$ was followed by linearly increase in soil $\mathrm{pH}$, available $\mathrm{P}$, exchangeable $\mathrm{K}, \mathrm{Ca}, \mathrm{Mg}$ and $\mathrm{CEC}$ (Ilham et al., 2019). Application of dolomite up to 2,000 $\mathrm{kg} \mathrm{ha}^{-1}$ on peat soil revealed rice growth and yield increase in linearly trend (Idwar et al., 2004). When soil acidity in peat soil was range between $\mathrm{pH} 5.0$ and $\mathrm{pH} 5.6$, application of lime for amelioration soil acidic constraint for rice growth required dolomite from $2,600 \mathrm{~kg} \mathrm{ha}^{-1}$ to $5,490 \mathrm{~kg} \mathrm{ha}{ }^{-1}$ (Gultom and Mardaleni, 2014). Neutralizing soil acidity and improving nutrient content in cultivated peat soil, it should implemented ameliorants and fertilizers applied. Amelioration treatments could improve soil $\mathrm{pH}$, raise available nutrients and increase in soil adsorption for nutrient exchanges (Ratmini, 2012).

SP36 applied gave effect $3.3 \%$ was not significant to rice yields. Nitrogen and phosphorus are applied to agricultural systems in large quantities and a deficiency of either nutrient leads to yield losses and triggers complex molecular and physiological responses (Vinod and Heuer, 2012). Deficiency in phosphorus can severely limit rice yields (Islam et al., 2008). P deficiency caused 
a significant reduction in the net photosynthesis rate in rice plants (Balemi and Negisho, 2012). Phosphorus deficiency on rice can significantly reduce yields often noticed on low pH soils (Fageria, 2014).

$\mathrm{KCl}$ fertilizer applied also had a minute effect to the rice yield. Application doses of SP36 and $\mathrm{KCl}$ applied by the farmers almost equal to the recommend dose but the effects of these were very tiny to the rice yields. Lower rice yield when fertilizers applied in higher amount could be caused by continuous leaching of soluble minerals. Phosphorus could lose from root zone about $90 \%$ within 15 days through continuous leaching (Maas et al., 2000). Furthermore, potassium was the easiest nutrient lost from root zone because potassium was a mobile one charge cation. Also, lime applied in peat in short time reacted with peat acid solution $\mathrm{H}$-organic to be $\mathrm{Ca}$ - and $\mathrm{Mg}$ organic in organic colloid and then carried away with sub surface water flow lose from paddy fields. Efficiencies of N, P and K were only 24.8, 10 and $25.4 \%$ in rice paddy, respectively, most of which is lost through volatilization and leaching (Liu et al., 2019).

The NPK fertilizer applied was not significant effect to improve rice yields cultivated on the two marginal peat soils. The optimum dose NPK needed for the highest yield of rice cultivated on the two marginal peat soils was $912 \mathrm{~kg}$ NPK ha-1. The optimum NPK doses mean $136.8 \mathrm{~kg} \mathrm{~N}, 136.8 \mathrm{~kg} \mathrm{P}$ and $136.8 \mathrm{~kg} \mathrm{~K} \mathrm{ha}^{-1}$ could increase rice yield to $4,778 \mathrm{~kg} \mathrm{ha}^{-1}$.

Urea affected significantly to the rice yield in two peat soils but its applied was not efficient. High $\mathrm{N}$ loss and low $\mathrm{N}$ use efficiency, caused by high $\mathrm{N}$ fertilizer inputs and inappropriate fertilization patterns, have become important issues in the rice (Oryza sativa $\mathrm{L}$ (Liu et al., 2016). Improper $\mathrm{N}$ management during cultivation due to improper management may cause the missing of $\mathrm{N}$ application during a certain developmental stage (Xiong et al., 2018). Nitrogen, the most important mineral nutrient for plants, is critical to agricultural production systems. Furthermore, N deficiency severely affects rice growth and decreases rice yields (Zhang et al., 2015). The amount of urea applied by the farmers was far below the recommend dose for high productivity $300-400 \mathrm{~kg} \mathrm{ha}^{-1}$. The optimum dose of urea needed for the highest rice yield projected $4,559 \mathrm{~kg} \mathrm{ha}^{-1}$ on two peat soils was $567 \mathrm{~kg} \mathrm{ha}^{-1}$.

In order to reach equal productivity with average rice field in Bengkulu Province and national rice productivity, application of fertilizers by the local farmers should be added in huge amount of these fertilizers. However, fertilizers application to paddy fields should be managed properly in order to avoid nutrients loses from root zones because of sub surface flow away. Nutrients lose through drainage leaching caused inefficiency nutrient availability from fertilizers applied in porous peat soils should be concerned for implementation good agricultural practices in paddy cultivation in peat soils (Pulunggono et al., 2019).

\section{Conclusion}

Rice cultivations on irrigated marginal peat soils in Bengkulu Province produced lower yield than irrigated rice field in mineral soils. In order to get maximum yield, the fertilizers for paddy cultivation in peatland needed enormous dose of nitrogen, phosphorus, potassium in combination with good agricultural practices to prevent nutrients loses carried away by subsurface drainage. Cultivation of marginal peat soil for rice production should be initiated with ameliorant to overcome the acidic constraint by broadcasting lime Optimum level of fertilizers were $567 \mathrm{~kg}$ Urea ha ${ }^{-1}, 323 \mathrm{~kg} \mathrm{SP} 36 \mathrm{ha}^{-1}, 790 \mathrm{~kg} \mathrm{KCl} \mathrm{ha}{ }^{-1}$, or $912 \mathrm{~kg}$ NPK compound ha ${ }^{-1}$.

\section{Acknowledgment}

This study was supported by research grant from LPPM of the University of Bengkulu, contract no. 2008/UN30.15/PG/2020, June 23, 2020.

\section{Author's Contributions}

Muhammad Faiz Barchia: Designed the research plan, participated in all experiments and contributed to the writing of the manuscript.

Andi Ishak: Verified the analytical methods, analyzed the data.

Satria Putra Utama: Carried out the experiments.

Ridha Rizki Novanda: Coordinated the mouse work.

\section{Ethics}

Concerning peat conservation and rice production problems, there is no conflict of interest from authors facing with them.

\section{References}

Akmaldi, W., Barchia, M. F., \& Ganefianti, D. W. (2020). Relationship Characteristics Soil, Fertilization and Outcome of Rice in Village Lubuk Pinang, Mukomuko. TERRA: Journal of Land Restoration, 3(1), 15-22.

Aksani, D., Budianta, D., \& Hermawan, A. (2018). Determination of Site-specific NPK Fertilizer Rates for Rice Grown on Tidal Lowland. Journal of Tropical Soils, 23(1), 19-25.

Alexopoulos, E. C. (2010). Introduction to multivariate regression analysis. Hippokratia, 14(Suppl 1), 23.

Allamah, A., Hapsoh, H., Wawan, W., \& Dini, I. R. (2018). The Growth and Yield of Rice (Oryza sativa L.) with Organic and Inorganic Fertilizer Application by Cellulolytic Microbes in Peat. Indonesian Journal of Agricultural Research, 1(3), 295-306. 
Aprillya, M. R., Suryani, E., \& Dzulkarnain, A. (2019a). The Analysis of Quality of Paddy Harvest Yield to Support Food Security: A System Thinking Approach (Case Study: East Java). Procedia Computer Science, 161, 919-926.

Aprillya, M. R., Suryani, E., \& Dzulkarnain, A. (2019b). System Dynamics Simulation Model to Increase Paddy Production for Food Security. Journal of Information Systems Engineering and Business Intelligence, 5(1), 67-75.

Astuti, U. P., Wahyu, W., \& Andi, I. (2011). Faktor yang Mempengaruhi Alih Fungsi Lahan Pangan Menjadi Kelapa Sawit di Bengkulu: Kasus Petani di Desa Kungkai Baru.

Azhari, R., Rusman, B., Kasim, M., Syarif, A., Reflinaldon, R., Yasin, S., ... \& Junaidi, J. (2017). Tantangan Pengembangan Padi Di kabupaten Kepulauan Mentawai. Jurnal AGRISEP Kajian Masalah Sosial Ekonomi Pertanian dan Agribisnis, 16(1), 41-56.

Balemi, T., \& Negisho, K. (2012). Management of soil phosphorus and plant adaptation mechanisms to phosphorus stress for sustainable crop production: A review. Journal of Soil Science and Plant Nutrition, 12(3), 547-562.

BPS-Statistics Bengkulu. (2020). Luas Panen, Produktivitas, dan Produksi Padi Menurut Kabupaten/Kota di Provinsi Bengkulu, 2018-2019. https://bengkulu.bps.go.id/publication.html

BPS-Statistics Indonesia. (2020). Statistik Indonesia 2020. Badan Pusat Statistik. Jl. Dr. Sutomo 6-8 Jakarta 10710 Indonesia.

https://www.bps.go.id/publication/2020/04/29/e9011b3 155d45d70823c141f/statistik-indonesia-2020.html

Buresh, R.J. (2010). Nutrient best management practices for rice, maize and wheat in Asia. World Congress of Soil Science. 1-6 August 2010, Brisbane, Australia.

Dogbe, W., Sogbedji, J. M., \& Buah, S. S. J. (2015). Site-specific nutrient management for lowland rice in the northern Savannah zones of Ghana. Current Agriculture Research Journal, 3(2), 109-117.

Duan, Y. H., Zhang, Y. L., Ye, L. T., Fan, X. R., Xu, G. H., \& Shen, Q. R. (2007). Responses of rice cultivars with different nitrogen use efficiency to partial nitrate nutrition. Annals of Botany, 99(6), 1153-1160.

Ekpenyong, E. J., Ime Okonnah, M., \& Donatus John, E. (2008). Polynomial (nonlinear) regression method for improved estimation based on sampling. JApSc, $8(8), 1597-1599$.

Fageria, N. K. (2014). Yield and yield components and phosphorus use efficiency of lowland rice genotypes. Journal of Plant Nutrition, 37(7), 979-989.

Gultom, H., \& Mardaleni. (2014). Adaptation test of several varieties of rice (Oryza sativa L) and dolomit lime on peatland. Jurnal Dinamika Pertanian, vol. 29 no 2 p.145-152.
Hikmatullah, H., \& Sukarman, S. (2014). Physical and Chemical Properties of Cultivated Peat Soils in Four Trial Sites of ICCTF in Kalimantan and Sumatra, Indonesia. Journal of Tropical Soils, 19(3), 131-141.

Idwar, S. S. I., Hamzah, A., Dahono, E., \& Zulkipli. (2004). Keragaan pertumbuhan dan produksi padi sawah (Oryza sativa L.) varietas IR-64 di tanah gambut yang diberi dolomit dan tembaga $(\mathrm{Cu})$ melalui daun. Sagu, vol. 3 no 1 p. 42-50. https://ejournal.unri.ac.id/index.php/JSG

Ilham, F., Prasetyo, T. B., \& Prima, S. (2019). Pengaruh Pemberian Dolomit Terhadap Beberapa Sifat Kimia Tanah Gambut dan Pertumbuhan Serta Hasil Tanaman Bawang Merah (Allium ascalonicum L). Jurnal Solum, 16(1), 29-39.

Islam, M. A., Islam, M. R., \& Sarker, A. B. S. (2008). Effect of phosphorus on nutrient uptake of Japonica and Indica rice. Journal of Agriculture \& Rural Development, 6(1), 7-12.

Jaya, A., Inoue, T., Limin, S. H., Darung, U., \& Banuwa, I. S. (2018). Microclimate of developed peatland of the mega rice project in Central Kalimantan. Journal of Tropical Soils, 15(1), 63-71.

Kechavarzi, C., Dawson, Q., \& Leeds-Harrison, P. B. (2010). Physical properties of low-lying agricultural peat soils in England. Geoderma, 154(3-4), 196-202.

Liu, Q., Ma, H., Lin, X., Zhou, X., \& Zhao, Q. (2019). Effects of different types of fertilizers application on rice grain quality. Chilean Journal of Agricultural Research, 79(2), 202-209.

Liu, X., Wang, H., Zhou, J., Hu, F., Zhu, D., Chen, Z., \& Liu, Y. (2016). Effect of $\mathrm{N}$ fertilization pattern on rice yield, $\mathrm{N}$ use efficiency and fertilizer-N fate in the Yangtze River Basin, China. PloS one, 11(11), e0166002.

Maas, A., Kabirun, S., \& Nuryani, S. (2000). Laju dekomposisi gambut dan dampaknya pada status hara pada berbagai tingkat pelindian. Jurnal Ilmu Tanah dan Lingkungan, 2(2000).

Maftu'ah, E., \& Nursyamsi, D. (2019). Effect of biochar on peat soil fertility and NPK uptake by corn. AGRIVITA, Journal of Agricultural Science, 41(1), 64-73.

Maftu'ah, E., Ma'as, A., \& Purwanto, B. H. (2014). N, P and $\mathrm{K}$ storage efficiency on degraded peat soil through ameliorant application. Journal of Degraded and Mining Lands Management, 1(4), 187.

Mariyono, J. (2014). Rice production in Indonesia: Policy and performance. Asia Pacific Journal of Public Administration, 36(2), 123-134.

Masganti, N., \& Nurmili Y. (2017). Increasing rice yield in tidal swamp land by $\mathrm{P}$ fertilizer and rice straw compost. Jurnal Tanah dan Iklim, vol. 41 no. 1 , p. 17-24

https://media.neliti.com/media/publications/132893ID-peningkatan-produktivitas-padi-di-lahan.pdf 
Moilanen, M., Saarinen, M., \& Silfverberg, K. (2010). Foliar nitrogen, phosphorus and potassium concentrations of Scots pine in drained mires in Finland.

Mustamo, P., Hyvärinen, M., Ronkanen, A. K., \& Kløve, B. (2016). Physical properties of peat soils under different land use options. Soil Use and Management, 32(3), 400-410.

Mustikarini, E. D., \& Santi, R. (2020). The empowerment strategy of newly irrigated rice field farmers through LEISA. Society vol 8 no. 1 p. 23-36.

Ompusunggu, D. S., Purwanto, B. H., Wulandari, C., \& Utami, S. N. H. (2020). Effect of salted fish waste and cow manure on NPK availability and uptake of lowland rice on peat soil in Pelalawan Riau. Agricultural Science, vol. 5 no. 1 p. 11-18.

Page, S. E., Banks, C. J., \& Rieley, J. O. (2007). Tropical peatlands: distribution, extent and carbon storage-uncertainties and knowledge gaps. Peatlands International, 2(2), 26-27.

Pulunggono, H. B., Anwar, S., Mulyanto, B., \& Sabiham, S. (2019). Dinamika Hara Gambut Pada Penggunaan Lahan Hutan Sekunder, Semak Dan Kebun Kelapa Sawit. Jurnal Pengelolaan Sumberdaya Alam dan Lingkungan (Journal of Natural Resources and Environmental Management), 9(3), 692-699.

Ratmini, N. S. (2012). Characteristics and Management of Peatland for Agricultural Development. Jurnal Lahan Suboptimal: Journal of Suboptimal Lands, 1(2).

Rieley, J. O. Wüst, R. A. J., Jauhiainen, J. Page, S. E., Wösten, H., Hooijer, A., Siegert, F., Limin, S. H., Vasander, H., \& Stahlhut, M. (1996). Tropical peatlands: carbon stores, carbon gas emission and contribution to climate change process. https://edepot.wur.nl/41970

Riwandi, Barchia, M. F., \& Hadiningsih, M. 2009. Penilaian Kesuburan dan Kesehatan Tanah dengan Pendekatan Kinerja Tanah dan Bioassay Tanaman. University of Bengkulu. http://repository.unib.ac.id/251.pdf

Sahfitra, A. A., Hanudin, E., Wulandari, C., \& Utami, S. N. H. (2020). NPK uptake and growth of maize on ombrogenous peat as affected by the application of mycorrhizal fungal multi-spores and compound fertilizers. Ilmu Pertanian (Agricultural Science), 5(2), 76-85.

Samijan, S., Prastuti, T. R., \& Warsito, W. (2017). Evaluasi Lapang Rekomendasi Pemupukan Padi Sawah Berdasarkan Pemupukan Hara Spesifik Lokasi Berbasis Internet di Jawa Tengah Indonesia. PLANTA TROPIKA: Jurnal Agrosains (Journal of Agro Science), 5(1), 23-33.
Sulaiman, A. A., Simatupang, P., Kariyasa, I. K., Subagyono, K., Las, I., Jamal, E., Hermanto, Syahyuti, Sumaryanto, \& Suwandi. (2018). Sukses Swasembada Indonesia Menjadi Lumbung Pangan Dunia 2045.IAARD Press: Jakarta, Indonesia. http://repository.pertanian.go.id/handle/12345678 9/8623

Surahman, A., Soni, P., \& Shivakoti, G. P. (2018). Are peatland farming systems sustainable? Case study on assessing existing farming systems in the peatland of Central Kalimantan, Indonesia. Journal of Integrative Environmental Sciences, 15(1), 1-19.

Septiyana. Sutandi, A., \& Indriyati, L. T. (2017). Effectivity of Soil Amelioration on Peat Soil and Rice Productivity. Journal of Tropical Soils, 22(1), 11-20.

Vinod, K. K., \& Heuer, S. (2012). Approaches towards nitrogen-and phosphorus-efficient rice. AoB Plants, 2012.

Wahyunto, Ritung, S., Suparto, \& Subagjo, H. (2004). Sebaran Gambutdan Kandungan Karbon di Sumatera dan Kalimantan. Wetlands International Indonesia Programme PO. Box 254/BOO-Bogor 16002 Indonesia. http://wetlands.or.id

Wheeler, B. D., \& Proctor, M. C. F. (2000). Ecological gradients, subdivisions and terminology of northwest European mires. Journal of Ecology, 88(2), 187-203.

Xiong, Q., Tang, G., Zhong, L., He, H., \& Chen, X. (2018). Response to nitrogen deficiency and compensation on physiological characteristics, yield formation and nitrogen utilization of rice. Frontiers in Plant Science, 9, 1075.

Yanti, R. T., Ridwan, M., \& Rospida, L. (2013). Analysis displace function farm agriculture of crop food rice field to sector plantation of oil palm and rubber and affect to production paddy sub-province Seluma, Province of Bengkulu. Jurnal Ekonomi dan Perencanaan Pembangunan, vol. 5 no 2 p. 64-75. http://repository.unib.ac.id/11032.pdf

Ye, T., Li, Y., Zhang, J., Hou, W., Zhou, W., Lu, J., ... \& Li, X. (2019). Nitrogen, phosphorus and potassium fertilization affects the flowering time of rice (Oryza sativa L.). Global Ecology and Conservation, 20, e00753.

Young, R. A., \& Loomis, J. B. (2014). Determining the economic value of water: concepts and methods. Routledge.

Zhang, Y., Tan, L., Zhu, Z., Yuan, L., Xie, D., \& Sun, C. (2015). TOND1 confers tolerance to nitrogen deficiency in rice. The Plant Journal, 81(3), 367-376.

Zulkarnain, H. (2016). Memori Tugas Kepala Balai Wilayah Sungai Sumatera VII. Direktorat Jenderal Sumber Daya Air Kementerian Pekerjaan Umum dan Perumahan Rakyat.

http://bws.direightion.com/assets/.pdf 